\title{
LABOR PROBLEMS OF THE TRANSPORTATION INDUSTRY
}

\author{
ELI L. Oliver*
}

\section{INTRODUCTION}

Labor problems of the transportation industry have been given a great deal of publicity during the past year. Most of the major American airlines have been shut down by strikes of one group or another in the recent past. ${ }^{1}$ James Hoffa and the International Brotherhood of Teamsters have been starring in congressional hearings, court proceedings, and television shows, as well as in magazine and newspaper stories. Local transit labor disputes have been on the front pages in several of the largest cities. A brief boycott of "runaway" ship lines seems to be the prelude to a world-wide maritime labor conflict. Railway management officials fired in February 1959 the first gun in what has become the most serious railway labor dispute in a generation, ${ }^{2}$ while unemployment, though less publicized, is among the most critical of current transportation problems. ${ }^{3}$

These situations have not arisen suddenly; the problems now boiling over have been heating up for a long time. Most of them are current manifestations of continuing conflicts, closely related to underlying economic and governmental conditions. Some types of labor problems are common to all industry, but each industry's problems have peculiar features arising out of its own individual characteristics. This is particularly true of transportation. Its special features, though doubtless well known, should be recalled in summary as a preliminary to any consideration of new legislation affecting transportation employment.

Physically, the several divisions of the industry are engaged in the transportation: (a) of goods and passengers; (b) by ship, airplane, train, and motor truck and bus; and (c) either locally, between cities, nationally, or internationally. From a strictly economic point of view, these forms of transportation may be considered either as competitive with one another or as supplementary. Integration of all types of transportation is industrially feasible; the Canadian Pacific transportation system owns and operates rail lines, air lines, bus lines, truck lines, and ships on the Great Lakes and both the Atlantic and Pacific Oceans. The Canadian National Railway, owned by the Canadian Dominion Government, is the center of a similarly integrated transportation system, the two integrated systems competing throughout the country. Government regulation in the United States has insured

- A.B. I9I8, University of Minnesota. Head, Washington Office, Labor Bureau of Middle West.

Traffic World, Dec. 6, 1958, pp. 15, 42; id., Jan. 17, 1959, p. 21.

${ }^{2} 1959$ Target: Featherbedding, Railway Age, Feb. I6, 1959, p. 9; Management 'Featherbed'?, id., Feb. 23, 1959, pp. 10, 58 .

Tranisport Economics, Jan. I959, p. 5. 
that, with few exceptions, each of these various types of transportation facilities is owned and operated separately from the others.

Historically, these transportation media were developed separately, and each of them in segments. Highways, railways, airlines, and waterways were built to connect particular localities, or to serve specific needs. Their subsequent linking into through routes made manifest the duplications, gaps, and circuitous courses that resulted from piece-meal construction. The distribution of industries and population, particularly in the West, was largely determined by the availability of transportation, and that distribution later tended to perpetuate existing transportation routes. Many of the major problems of the railroad industry and its employees have their origin in efforts to correct the results of unplanned early railroad expansion.

Added to these physical, economic, and industrial characteristics, as a major factor in the settling of labor relations, is the dominating public interest in safe, efficient, uninterrupted, economical, adequate, and nondiscriminatory transportation service. The public interest led, in turn, to the elaboration of a complex web of governmental regulation, at every level and over every form of transportation. Though the regulation was occasioned by public reaction to high rates, discriminations, and other abuses in early transportation history, it has not all been negative or prohibitory. In particular, governmental assistance or subsidy has been a factor in the development and maintenance of all types of transportation facilities; in local transit, public ownership and operation have become the predominant practice in the largest American cities.

This network of governmental regulation has a multiple relationship to transportation employees. Part of the network deals directly with labor conditions, but every regulation of any section of the industry inevitably has at least an indirect effect upon the employees. Labor organizations, particularly those of railway workers, have tried to influence governmental regulation in a manner that would minimize its harmful effects on their members. Railway unions have led all labor, in some instances, in establishing basic labor rights; and in other instances, they have gained substantial improvements through legislation or administrative action. This complex relationship between transportation unions and the various forms of government regulation of the industry must be kept in mind in considering additional legislation on any transportation labor problem.

Another significant factor, tying in with existing governmental regulation, is that the form of labor organization has mirrored the divisions, structure, and history of the transportation industry. There are two major divisions in the form of labor organization, and there is a parallel division in the governmental handling of labor conditions.

In the three sections of the industry that are most definitely national in scopethe railways, airlines, and waterways-labor organization is predominantly on a craft basis. There are twenty standard international railway labor unions; there 
are at least three separate organizations of airline flight personnel, and separate craft unions of nonoperating employees; there are separate organizations of licensed and unlicensed maritime workers, separate craft organizations of shipmaintenance men, and separate unions of longshoremen. In each of these three types of transportation, the men who operate the vehicles are in the minority; they are outnumbered by clerical, maintenance, and other groups by four or five to one. The fact that these operating men are in the minority, but have the greatest collective bargaining power, led to their separate organization. On the railways, only the train and engine service groups and the telegraphers had the power to organize and win bargaining rights in the era when both government and employers were most determined in opposition. Operating groups in all three of these sections of the industry have felt that inclusion in a general union, where they would be greatly outnumbered, would dilute their bargaining power and would not give as favorable action on their wage rates or as good an understanding or handling of their special working conditions as could be secured through craft action.

Each of these three sections of the industry has its own separate unions of operating employees. Some nonoperating unions, on the other hand, have membership in all of these (and to some extent in other) sections of the industry. The Brotherhood of Locomotive Engineers, the Order of Railroad Conductors. and Brakemen, the Brotherhood of Locomotive Firemen and Enginemen, the Brotherhood of Railroad Trainmen, and the Switchmen's Union of North America are limited, almost entirely, to the railroad industry; ${ }^{4}$ the International Association of Machinists, on the other hand, has membership among maintenance workers in all three of these sections of the industry, and the Brotherhood of Railway and Steamship Clerks, Freight Handlers, Express and Station Employees also represents airline employees of the classes listed in the union name.

Labor conditions of employees of railways, airlines, and waterways are federally regulated, with the first two groups coming under the Railway Labor Act. ${ }^{5}$ Legislation somewhat similar to this Act, governing labor relations in the merchant marine, was adopted in $1936,{ }^{6}$ but expired by its own terms in $194 \mathrm{I}$ and was not extended. In each of these sections of the industry, other federal regulation. affects the employees, directly and indirectly.

The make-up of the labor force in motor-truck and bus and street-car transportation is basically different from that of rail, air, and water transportation. In local transit (a term used to include street-car, bus, subway and elevated service), operating employees outnumber nonoperating by three to one. The same is true in over-the-road bus transportation. Truck drivers also outnumber nonoperating employees in truck transportation, both local and intercity. Neither

\footnotetext{
"There are exceptions; the Brotherhood of Railroad Trainmen does have, for example, a number of: agreements covering intercity bus drivers.

${ }_{44}$ Stat. 577 (1926), as amended, 49 Stat. I 189 (1936), 45 U.S.C. $\$ \$$ r51-88 (1952).

52 Stat. 965 (expired June 23, 194I).
} 
bus nor truck operating employees need be afraid of domination by nonoperating crafts. Local transit and over-the-road bus employees are organized in industrial union form-the great bulk of them in the Amalgamated Association of Street, Electric Railway, and Motor Coach Employes of America. Truck drivers, helpers, and warehouse and storage employees, with some other nonoperating employees, are in the International Brotherhood of Teamsters, a craft union in form, but almost industrial in intercity truck transportation. Although hours of service of intercity bus and truck drivers are limited by the Interstate Commerce Commission, under the Interstate Commerce Act, there is no federal regulation of collective bargaining, and no machinery for the settlement of labor disputes, for motor-bus or truck employees, except that which applies to all labor. Some states do have special statutory regulation of collective bargaining in local transit, and cities where transit facilities are publicly-owned have various provisions for fixing wages and working conditions (usually by collective bargaining, with one or another type of arbitration for ultimate settlement of disputes).

The Amalgamated Association has in its international constitution the requirement that its local unions must propose arbitration in any dispute that cannot be settled in negotiation; strikes are prohibited unless arbitration has been rejected by management. This constitutional requirement has been accompanied by agreements with management-or by equivalent action of local public-transit authorities -specifically providing for arbitration not alone of grievances, but also of disputes arising out of proposals for change in wages or working conditions. In motor-trucking, the International Brotherhood of Teamsters does have arbitration agreements but relies principally upon direct economic power in its collective bargaining with employers.

The AirLine Industry

Among these divisions of the transportation industry, the airlines have been most involved in strikes during $195^{8}$ and 1959 . Five major airlines were forced to suspend operations because of strikes in that period-American Airlines, Capital Airlines, Trans World Airlines, Eastern Air Lines, and Western Air Lines. Taken together, these airlines constitute fifty per cent of the air transportation industry. In each of those disputes, except that involving Western Air Lines, the full procedures of the Railway Labor Act were followed, including hearings before presidential emergency boards. Whether or not the National Mediation Board and the emergency boards functioning under the Act can be blamed for failing to bring about peaceful settlement of these disputes, the fact remains that they were unsuccessful.

The Railway Labor Act was originally drawn, and has since been amended, primarily to fit the needs of the railway industry. Congress, and the public generally, was so impressed with the early success of the Act that it seemed only 
necessary to add a title bringing air transportation under the Act to assure peace in that field. A similar suggestion was made, but abandoned, with respect to the maritime industry. Title two, covering airlines and their employees, was added to the Railway Labor Act in $1936 .^{7}$

The fallacy in this extension of the Act has now become clear. Railway managements and unions had had long experience in collective bargaining when they drew up the original Railway Labor Act together in I926. Both were accustomed to joint national action. Their maturity has been the principal factor in the success of the law. But the consummate ability of the late Dr. William M. Leiserson, Chairman of the National Mediation Board from I934 to 1939, and in I943 to I944 (at a time when airline labor problems were of minor importance), was largely responsible for the development of Board procedures fitted to the needs and character of the railway industry. Neither airline managements nor the organizations of flight personnel have the collective bargaining experience presupposed by Railway Labor Act procedures. Moreover, the National Mediation Board cannot now, without neglect of railway labor relations, undertake the adaptation of its staff and procedures to the very different conditions on the airlines.

Among those conditions is the failure, thus far, of both airline labor organizations and airline companies to develop necessary co-operation among themselves. Separate unions, bargaining separately with individual airlines on wages and working conditions that should at least be co-ordinated, present an almost insuperable problem to the kind of mediation or emergency board procedure contemplated in the Railway Labor Act. Separate collective bargaining at the moment has the further handicap that officers of one leading airline union fear impending technological change will lessen employment opportunities for their members-and are, accordingly, determined to take over at any cost the work done by members of another union. The absolute economic power of that "raiding" union makes its jurisdictional claim a menace to the industry and its patrons.

Under these circumstances, serious consideration should be given to the creation of a separate agency, by agreement or by law, to handle labor disputes on the airlines. Managements and unions alike should have learned from the "recent unpleasantness" that they must join in developing effective procedures for settling labor disputes. It is not appropriate here to suggest how those procedures should depart from accepted railway practice, but certainly much greater emphasis should be given to the encouragement of voluntary arbitration. Either the Secretary of Labor, the National Mediation Board, or the Senate Labor Committee might initiate an effort to get joint acceptance of new legislation if effective disputes procedure cannot be set up by agreement. Public hearings might point the way to such legislation, even if management and employees could not reach complete agreement on its provisions. In any case, it would be extremely unwise to base

\footnotetext{
${ }^{7} 49$ Stat. II 89,45 U.S.C. $\$ \$$ I8I-88 (I952).
} 
any amendment of the Railway Labor Act on these airline strikes, except whatever amendment is necessary to make explicit and definite the separation of railway and airline disputes machinery and procedure.

Air transportation will certainly increase greatly during the next decade. National dependence upon air transportation will perhaps never be so great as upon surface transportation, but the experience of the last years demonstrates that airline strikes can cause extreme inconvenience and heavy financial losses to the public served. Airline employees have been most unfairly dealt with on many occasions, and airline companies have suffered from unnecessary interunion friction. The whole field of airline labor relations should be carefully reconsidered by unions, managements, and public authorities to provide greater assurance of effective collective bargaining during the period of expansion of the industry just ahead. The latest series of disputes gave reason to believe that safety of air transportation is involved in airline labor relations. Whatever machinery and procedure is established for handling such disputes not only must be fitted to other characteristics of the industry, but must, above all, provide for definite, fair, technically sound, and final settlement of any question affecting safety of operationseither within the collective bargaining process itself or by reference to other airline regulatory agencies.

\section{II}

\section{The Trucking Industry}

The absence of federal regulation of collective bargaining in motor-truck transportation similar to that applying to railways and airlines is probably attributable to the fact that this mode of transportation has only recently become really significant nationally. In 1946 , motor trucks handled $81,600,000$ ton-miles of intercity freight, or 8.65 per cent of the United States' total. ${ }^{8}$ In 1957 , intercity motor truck traffic was $26 \mathrm{r}, 000,000$ ton-miles, or 19.3 per cent of the United States' total. ${ }^{\circ}$ Rail traffic totalled $643,000,000$ ton-miles in 1946 and 626,000,000 ton-miles in 1957. Intercity truck traffic has thus increased from 12.7 per cent to $4 \mathrm{r} .7$ per cent of rail freight traffic in eleven years. But motor-truck labor problems are growing even faster than their operations.

Publicity attendant on the investigations of the International Brotherhood of Teamsters and its officials may have obscured the fact that there are two major problems being outlined. The first lies in any misdeeds of which the officials may be guilty. The second lies in the danger of national labor conflict in the industry. The two, of course, are interrelated, in that if the union is in fact controlled by dishonest men, there is danger that destructive strikes may be called without real justification or for improper purposes.

The central fact is that the International Brotherhood of Teamsters was organized and adapted to function locally, especially in the construction industry. That

\footnotetext{
${ }^{8}$ ICC, Statement No. 544, InTercity Ton-Miles 1939-I952, at 4, 6, tables 2 and 3 (1954).

${ }^{9}$ ICC 72D ANN. REP. Io (1958).
} 
industry, like many service trades and small-scale manufacturing industries, was characterized by ruthless, anarchic competition. Imposition of "slave and starve" labor conditions by some employers was often a part of that competition. The sweat shop in the apparel industries was one of the worst illustrations of those conditions. Neither local nor federal government did anything effective to prevent unfair competition or maintain order. The result was that owners and labor organizations themselves began to police their industries by whatever means were available. Local truck drivers were an important factor in those efforts at selfregulation. Not unnaturally, these police operations frequently led to abuses, by individual businessmen as well as individual union officials. Nonlegal sanctions for more or less legitimate purposes merged into illegal coercion for indefensible purposes. The unofficial police sometimes became violent and corrupt-which has happened, occasionally, even to official police. Some of the methods of legitimate self-policing employed by business and labor groups were also used with modifications to set up and operate "rackets."

Another conditioning factor is that union organizing efforts in the years when the Teamster pattern was being set were met with violence, bribery, frame-ups, and all the techniques in the manual of the private detective agency, often with the assistance of local judges, police, and public officials. Union representatives fought back, and some of them "bettered the instruction" of employer representatives. Being arrested for union activity was no disgrace in that era. Building trades workers were organized in such continuing savage warfare.

Whatever the reasons, there has been too much violence and corruption in the construction industry, as well as in other local industries, in many communities. Labor relations have been infected with the malady, and the teamsters have not been immune. Teamster union officials exposed to and trained for such local conditions have suddenly become national officials with great responsibility in a major section of the transportation industry. The industry is national, though national collective bargaining has not yet begun; even regional bargaining is a very recent development. Teamster officials have come from their local battles "not in entire forgetfulness" and certainly not "trailing clouds of glory." "They have not yet learned or adapted themselves to the ethical standards of other national transportation unions-unions that have been free up to now from any suggestion of corruption. Those other unions, and American labor generally, are bringing tremendous pressure to bear upon the International Brotherhood of Teamsters, at all levels, to "clean house." Congress has passed legislation seeking to deal with abuses of the kind revealed in the McClellan Committee investigations. ${ }^{10}$ The danger, of course, is that in the effort to clean up the enfants terribles of the labor movement, the legislation may be such as to "toss the baby out with the bath water."

\footnotetext{
${ }^{10}$ Labor-Management Reporting and Disclosure Act of 1959,73 Stat. 519.
} 
The second half of the motor-truck labor situation needs immediate attention. Congress might well consider legislation to facilitate the peaceful settlement of disputes affecting intercity motor transportation of commodities. There is little likelihood of getting co-operation in drafting such legislation between the industry and the International Brotherhood of Teamsters (analogous to that in the railway industry preceding the passage of the Railway Labor Act of 1926 referred to above). But in view of the rapid development of the industry and the character of its collective-bargaining relations, some beginning at least should be made. Here, again, it is important that the handling of railway labor disputes not be jeopardized by the addition of a motor-truck section to the Railway Labor Act, although its basic principles could be adapted to truck transportation. ${ }^{11}$ Under a separate administrative agency, perhaps the Federal Mediation and Conciliation Service, motor-truck legislation might well include specific provision for mediation, voluntary arbitration, and governmental fact-finding, with prohibition of strikes or lockouts until such procedures had been followed. The effect of such legislation not only would be a regularizing of collective bargaining and a protection to the public, but would also lessen the opportunity for any "undesirable" among teamster union officials to misuse his power by threatening or calling "quickie" strikes for improper objectives.

The need for such legislation was not really increased by the announced intention of James Hoffa, President of the International Brotherhood of Teamsters, to set up a Conference of Transportation Unity in alliance with other transportation unions. Maritime or waterfront labor organizations might find the assistance of the teamsters' union of great value in some of their current disputes with ship operators. But alliance with those unions would add very little to the economic power of the teamsters. Only by inducing railway labor to accept his leadership, or at least to work with him, could Mr. Hoffa increase significantly the power of his own organization. No one with the slightest knowledge of the railway unions, their leadership, their policies, or their history could entertain for a moment the idea that such an alliance is possible. Mr. Hoffa himself must know that he could not get railway labor co-operation. He should have realized, also, that the threat of a comprehensive transportation labor alliance under his leadersip-however empty the threat really is-could only increase the pressure for court action and legislation to deal with conditions allegedly found in the Teamsters. To some observers of these developments, it seems that Mr. Hoffa is "swinging wildly," a probable indication that he is about to "strike out." Certainly it would be a mistake to try to deal by legislation or any kind of regulation with that phase of the truck-driver situation.

\footnotetext{
${ }^{21}$ Since both airline and motor-truck labor relations are as yet undeveloped and formless, it might be possible to deal with both areas through a single governmental agency. Tying that agency to the National Mediation Board (railway) in any but a loose administrative fashion, however, could only impair the functioning of both.
} 
III

\section{The Shipping Industry}

Conditions closely analogous to those responsible for the violent labor conflicts in local industries in the r920's underlie the recently dramatized efforts of American maritime unions and the International Transportworkers' Federation (ITF) to bring the "Panlibhonco"12 runaway ship operators back under accepted labor standards. ${ }^{13}$ The common feature in these apparently widely different situations is the attempt to establish minimum labor standards, by legislation and by collective bargaining, where competitors serving the same market can evade those standards and operate with substantially lower wages and inferior working condiditions.

In their early efforts at organization, workers in the construction industry, in service trades, and in such light small-scale industries as apparel manufacturing were able to improve labor standards in particular plants or areas. Many employers were very willing to co-operate in making such improvements. Some states were willing, by legislation, to set reasonable minimum standards for factory workers. But other employers and other states saw in that progress only an opportunity for them to undercut competitors who had agreed or were by law compelled to maintain fair labor standards. Trade unions and employers alike realized the necessity for complete labor organization of strictly local industry. State government officials came to understand that only federal legislation (enforced by an administration and officials genuinely sympathetic to its purposes) could make minimum legislative standards effective. The rapid development of labor organization since 1933 and the passage of the Fair Labor Standards Act, ${ }^{14}$ National Labor Relations Act, ${ }^{15}$ and the Social Security and Unemployment Compensation $\mathrm{Act}^{1 \mathrm{~B}}$ have done a great deal to limit the competitive advantage possible through imposition of low labor standards. Nevertheless, the "runaway shop" remains a major problem to American labor and industry.

That problem, interstate in other industries, is international in maritime transportation. Federal legislation in the United States had even by 1940 accomplished a great deal in improving conditions for all American ship-operating, maintenance, and waterfront workers. Labor organization in this country and in the maritime nations of western Europe became virtually complete at the end of World War II. The combination of collective bargaining and governmental regulation established standards that were high as compared with prewar conditions and with those prevailing among maritime workers of nations with negligible merchant marines. American wages and other conditions are substantially better than those

${ }^{12}$ See p. 12 infra.

${ }^{13}$ Becu, A Unique Trade Union Action, ig Int' Jan. 22, 1959, p. 62, col. 3; id., Jan. 23, 1959, p. 49, col. 2; id., Jan. 28, 1959, p. 6r, col. 4 .

1452 Stat. 1060 (1938), as amended, 29 U.S.C. \$\$ $201-19$ (1952).

${ }^{28} 49$ Stat. 449 (1935), as amended, 29 U.S.C. 55 15I-66 (1952).

${ }^{10} 49$ Stat. 620 (1935), as amended, 42 U.S.C. $\$ \$ 301-1305$ (1952). 
of European maritime workers, which are, in turn, far superior to those of nonmaritime nations.

Thus far, however, there has been nothing to prevent the transfer of ship operations from the United States or any of the leading maritime nations to registry under the flag of any other country. American shipowners particularly, but many from other leading nations as well, have taken advantage of this opportunity to escape governmental and collective bargaining standards. The four nations. whose "hospitality" to foreign ship companies has been most used are Panama, Liberia, Honduras, and Costa Rica (hence "Panlibhonco"). The problem had already become very serious, and strong labor protests were being made, when by $1950,3,300,000$ tons of shipping were registered "as of" Panama, and 523,000 tons under the Honduran flag, with none recorded as under the Liberian and Costa Rican flags. ${ }^{17}$

By 1955, the four countries had 8,700,000 tons of shipping registered, with Liberia having almost half of the total. In 1956, the total had risen to 10,400,000 tons, Liberia alone having registered 5,600,000 tons. ${ }^{18}$ The "Panlibhonco" proportion of the world's merchant marine had risen from five per cent of the total to ten per cent in six years. Labor spokesmen estimate that at the end of 1958 , the shipping registered under the four flags had risen to $24,000,000$ tons, ${ }^{10}$ or sixteen per cent of the world total. By comparison, the total shipping under the American flag had dropped from 27,500,000 tons in 1950 to 26,100,000 tons in 1956, including Great Lakes shipping. ${ }^{20}$ These figures, though on not exactly the same basis, are a rough measure of the "Panlibhonco" problem.

Registry under these four "Hags of convenience" has been especially used by American oil companies. In I946, there were 268 tankers, of 4,200,000 tons, flying the American flag in foreign trade; in 1957 , there were only seventy-two tankers of $1,400,000$ tons. $^{21}$ Even since 1950 , the drop has been just over fifty per cent in the number, just under fifty per cent in the tonnage, of active tankers of American registry in foreign trade. American foreign trade, exports and imports, in tankers in I950 totaled Ir8,400,000 tons, fifty-three per cent of which was carried under the American flag; by 1957, of the total r08,300,000 tons of American foreign trade carried in tankers, only seventeen per cent was in ships of American registry.

On the other hand, not one ship was recorded by the Statistical Office of the United Nations as entering any port of Liberia, Honduras, or Panama in 1955 or, 1956 (1957 data have not yet been published). The total freight loaded and unloaded from ships entering harbors of the fourth country, Costa Rica, was only

\footnotetext{
${ }^{17}$ U.S. 'Dep't of Commerce, Statistical Abstract of the United States 932 (1952) [hereinafter cited as Statistical Abstract].

${ }^{18} \mathrm{Id}$. at $94 \mathrm{I}$ (1958).

${ }^{20}$ Sea Unions Pash Flag-Issue Drive; N.Y. Times, Jan. 23, 1959, p. 49, col. 2.

${ }^{20}$ Statistical Abstract 953 (1957); id. at 941 (1958).

${ }^{91}$ Id. at 593 ( 1958 ).
} 
700,000 tons in each of the two years. ${ }^{22}$ The four countries have no foreign trade by sea, but they are among world leaders in merchant marine registry.

Not all of the incentive for the "runaway" registration under these "flags of convenience" is in wages and working conditions. The ship operators are also able to avoid a substantial amount in taxation in the countries where the ships are actually owned. But the labor organizations of the maritime countries rightly concluded that the practice of "Panlibhonco" registration was a major threat to labor standards that have been established jointly by law and collective bargaining in all of the principal maritime countries.

The problem had been under consideration, and some protests had been made, since I949 at least. In the fall of 1958 , the ITF-a world organization of transportation unions-organized a protest boycott of the "Panlibhonco" ships. The boycott was planned to last only four days, from November $3^{0}$ to December 4 . American seamen's unions were most active in urging and organizing the movement; other world-wide labor groups, including the powerful International Confederation of Free Trade Unions, supported the boycott. Waterfront organizations affiliated with the ITF refused, during those four days, to unload or otherwise service the "runaway" ships. Omer Becu, able and energetic Secretary of the ITF, stated that the boycott was ninety per cent effective. ${ }^{23}$ One of the four "convenience" nations, Costa Rica, took steps just as the boycott began, to stop the use of its flag by the "runaway" ship operators. Newspapers and magazines in all of the maritime countries gave top publicity to the movement. It has been made clear, ever since the protest was first announced, that it is only a preliminary to a more widespread and continuing action if the "runaway" practice is not ended.

No one government can handle this problem satisfactorily, although a great deal can be done to minimize the abuse. The ITF has called upon the Intergovernmental Maritime Consultative Organization to take up the question as part of an effort to get simultaneous action by the several governments most involved. The real reliance of both the employees and the owners operating under flags of their own nations is upon the direct economic power of the labor groups, especially the longshoremen, the ship-repair workers, and the petroleum workers. Unions of these workers, coordinated through the ITF, can, without doubt, put enough pressure upon the ship operators to force them to re-establish union conditions, even though under "convenience" flags. The waterfronts of the world may see some vigorous action before the situation is stabilized. It is difficult to understand how United States Government officials can condone, as some of them seem to do, the evasion and undermining of our legal standard's by "runaway" American shipowners.

${ }^{22}$ Id. at 953 (1957); id. at 94r (1958).

${ }^{28}$ Sea Unions Push Flag-Issue Drive, N.Y. Times, Jan. 23, I959, p..49, col. 2. 
IV

\section{The RaIlRoad Industry}

Turning, finally, to railway transportation, it is to be noted that its current labor problems originate, for the most part, in technological changes both on the railways and in other types of transportation. These changes affect railroad employment in different ways, and there are open to railway employees a variety of courses for dealing with the problems. Of the changes in other sections of the industry, the development of highway and airline transportation has had a multiple effect on both passenger and freight traffic, and employees of the railways. Within the industry, movements toward merging of companies, facilities, or service have combined with increased automation to cause heavy displacement of railway workers.

Private automobiles handled about eighty-five per cent of intercity passenger traffic in 1950, the airways two per cent, and the railways eight per cent. ${ }^{24}$ In 1957, the rails and airways had about four per cent each, and private automobiles about eighty-nine per cent of intercity travel. ${ }^{25}$ Local transit has been even more affected by increased use of private automobiles, but no measurement of that local use has been made. Passengers carried by local transit facilities have declined approximately fifty per cent since 1950. Railway and local transit phases of this situation overlap in the commuter service operated into the largest cities by the railroads.

Passenger service differs from freight service and from manufacturing industry generally, in that technological change cannot increase its output per employee man-hour to the same degree. Passenger service is inescapably personal and individual. Progress in vehicles, power, accounting procedures, ticket machines, and station operation only makes more clear the fact that there can be relatively little reduction in the number of transportation employees per thousand passengers, unless volume increases substantially. Consequently, as wages rise-and they must go up with the general wage level-passenger costs rise. Those costs must be met from increased passenger revenues, or some other source must be found for funds to meet increasing expenses.

In the private-transit section of this problem, part of the difficulty is that longer hauls per passenger, resulting from outward movement of population in the cities, can only within narrow limits be met by increased fares; increasing general fares to meet higher average expense per passenger places an undue part of the cost on those riding short distances. But in the larger cities, mass transportation is vitally necessary if central business districts are to be kept alive. Traffic congestion is only increased by improving access of private automobiles to the central areas through freeways or other street and highway development. The need for local transit service for community purposes-transportation of school

"ICC, 65TH ANN. REP. 20 (195I).

2s ICC, 72D ANN. Rep. To (1958). 
children, for instance-cannot otherwise be met. These and related considerations have resulted in various kinds of subsidies for mass transportation in the larger cities; and in seven of these principal metropolitan areas, the facilities are now publicly owned and operated..$^{20}$

In the railway section of this general passenger problem, the managements claim that passenger service is operated at a deficit, made good out of freight revenues. The accuracy of that statement depends upon the method of accounting for the joint operations of the industry, but there can be no doubt that passenger service is less remunerative than freight service. Railway companies try to increase net passenger revenues by reducing or discontinuing service that has a high ratio of expenses to revenues. There is evidence that some roads would prefer to discontinue all passenger service. Any such reduction or discontinuance of service has an immediate effect on railway employment.

State regulatory commissions have had, until last year, major responsibility for permitting or prohibiting reductions of railway passenger service, including commuter operations. Local communities to be adversely affected by such changes have joined with railway workers in urging that service be maintained. Although very great reductions have been authorized by state commissions, the railways have felt that greater freedom should be given them. Railway officials in 1958 asked Congress to amend the Interstate Commerce Act so as to give final authority in any proposed reduction of service to the Interstate Commerce Commission. Congress, in the Transportation Act of $195^{8}$, granted that request; state commissions now have greatly reduced control over even intrastate railway service as a result of that law. ${ }^{27}$

It has already become clear that the operation of the new provisions of the Interstate Commerce Act will intensify the railway unemployment problem. The Commission has, and has exercised, the right in approving abandonments of service to attach conditions requiring a carrier to protect railway employees adversely affected. The conditions that have come to be considered standard under such circumstances are the "Burlington conditions," imposed by the Commission in Chicago, B. \& Q. R. Co. Abandonment. ${ }^{28}$ They include monthly supplementary or unemployment allowances to employees, continuance of employee rights during furlough, payment of moving costs to employees forced to move to retain employment, and reimbursement for losses by employees forced to sell homes. These particular conditions, attached to railway abandonments, are only a specific application of principles that have for years been given general acceptance by collective bargaining, by law, and by Commission action where proposed railway changes affected employees adversely. But in a decision under section I3a of the Interstate Commerce Act (added by the Transportation Act of 1958), the Commis-

\footnotetext{
${ }^{20}$ New York, Chicago, Los Angeles, Boston, Detroit, Cleveland, and San Francisco.

${ }^{27} 72$ Stat. 57I, 49 U.S.C.A. \$ I3a (Supp. 1958).

${ }^{28} 257$ I.C.C. 700 (1944).
} 
sion has now ruled that in the discontinuance of single trains, it does not have the power to impose conditions for the protection of employees. ${ }^{29}$ The resulting unemployment, in the one action, will be small; but to railway employees generally, the action of the Commission will be a major defeat and will threaten heavy future losses.

So far as the commuter aspects of the general railway program to curtail passenger service is concerned, it seems likely that some method of subsidy will be developed to secure continued operation. The problem is serious only in a relatively few large cities. One of those cities granted a temporary subsidy to one railroad, pending study and final action on the whole question. ${ }^{30}$ Different approaches will doubtless be used in different cities, some of them perhaps including public operation of commuter rail service as an adjunct to local transit facilities already publicly-owned.

But the discontinuance of passenger and other rail service under the new provisions of the Interstate Commerce Act may add greatly to an unemployment situation already acute. More than 200,000 railway workers were on the unemployment rolls in the later months of $195^{8}, 80,000$ more than in the same period of 1957. There were I40,000 drawing unemployment benefits in September, a month normally of high employment. Quantitatively this is a critical situation. ${ }^{31}$

Moreover, the quality of railway unemployment is as disturbing to the employees as the quantity. A detailed study of unemployment, made for the twelve-year period I946-58, analyzed the character of that unemployment. Of 308,000 who received unemployment compensation in the benefit year $1957-58$, r47,000 were over forty years of age. These older employees averaged more than eight weeks of unemployment compensation. Relative unemployment of senior employees was much greater in $1957-5^{8}$ than it had been in earlier years, and a greater proportion of the older unemployed exhausted the benefits to which they were entitled. Yet, the carrier employment policies seemed to have been established without regard to that situation. $^{32}$ In the calendar year I957, the carriers hired 95,000 new employees without previous experience in the industry, ${ }^{33}$ while 270,000 were being separated and 75,000 were unemployed long enough to exhaust their benefits, ${ }^{34}$ more than half of those

${ }^{29}$ Great Northern Ry. Co. Discontinuance of Service, Williston, N.D.-Watford City, N.D.-Richey, Mont., ICC, No. 20348, Feb. 6, 1959. Cf. Traffic World, Feb. II, 1959, p. I; Railway Agc, Feb. 16, I959, p. I4.

${ }_{30}$ The N.Y., N.H. \& H. R.R. was authorized to abandon its Old Colony Line in Massachusetts. The Special Legislative Railroad Commission recommended that the company be paid $\$ 900,000$ a year subsidy to keep the Old Colony line in service-the City of Boston to provide $\$ 250,000$ and remainder to be levied on 37 communities along the line. The state legislature and the courts approved the recommendation, and it was made effective. On July r, 1959, the Old Colony Line was abandoned; however, a section from Boston to Braintree (ro miles) was purchased by the Commonwealth of Massachusetts under authority of an act of the legislature, with the governor's approval. Moody's Transportation, July 18, 1958, p. 1317; id., July 4, 1958, p. 1338; id., July x, 1958, p. 1345; Passenger Transport, Sept. 4, 1959, p. 3 .

31 Railroad Retirement Board Monthly Review, Dec. 1958, p. 15.

${ }^{32}$ See statement from Office of Director of Research, Railroad Retirement Board, March I, 1957.

${ }^{38}$ Railroad Retirement Board Ans. Rep. 204, table E-2 (1958).

${ }^{34} I d$. at 186 , table D-27. 
over forty years of age. ${ }^{35}$ There is no record of those who found nonrailroad employment before exhausting their benefits.

The Railroad Retirement Board, administering: the Railroad. Unemployment Insurance Act $^{36}$ maintains a placement service and exerts all possible effort to persuade the carriers to hire experienced railroad men from among the unemployed. Those efforts have been attended with only slight success; in 1956, 27,000 unemployed claimants were placed, ${ }^{37}$ while the roads were hiring $140,000 \mathrm{em}$ ployees without railway experience. ${ }^{38}$ There has been a little improvement in recent months, but placement is still a small fraction of separations or of natural turnover.

Railway unemployment is a function, in part, of seasonal fluctuations, which railway employees consider to be susceptible of great reduction, with increased over-all efficiency, if management policies were changed. Part of railway unemployment results from the unification of facilities on individual roads or between railroads. Another part of the total is due to changes in equipment or processes, including automation, itself made more possible by consolidation of railroad offices or other facilities. Employment could be reduced over a long period, without unemployment, through natural turnover, if displaced employees were given positions made vacant by deaths, retirement, or resignation. This has been the basis of railway labor unemployment proposals for at least thirty years.

Railway employees have three approaches to this compound unemployment problem. It is a cardinal principle in both union and governmental railway labor policy that the savings resulting from unifications, consolidations, or similar changes should be used, in part, to cushion the effect of the resulting unemployment. This principle was written into the Emergency Railroad Transportation Act of $1933^{39}$ It is embodied in the "Washington Agreement of 1936 " between managements and unions, ${ }^{40}$ in the Interstate Commerce Act, ${ }^{41}$ and in many decisions of the ICC, even where the statutory requirement is not definite. ${ }^{42}$ Application of the principle includes allowance for the fact that many railway workers are employed in small towns, where there is no other employment, but where railway service has required skilled workers. In such towns, homes are often not for rent, and many railway employees have had to buy or build their own. When railroad reshuffling moves a service or a facility from such a town, the

${ }^{8 c} I d$. at 185 , table $\mathrm{D}-26$.

${ }_{52}^{36}$ Stat. 1094 (1938), 45 U.S.C. $\$ \$ 35 \mathrm{I}-67$ (1952).

${ }^{37}$ See statement by Bureau of Unemployment and Sickness Insurance, Railroad Retirement Board, March X, 1957.

${ }^{38}$ See Railroad Retirement Board Ann. Rep. I78, table D-2 (1957).

${ }_{40}^{30} 8$ Stat. 21I (expired June 17,1936 ).

${ }^{10}$ Hearings Before the House Committee on, Interstate and Foreign Commerce on H.R. 2531 , Omnibus Transportation Bill, 76th Cong., Ist Sess. pt. 2, at 23x-4x (1939).

${ }^{12} 24$ Stat. 380 ( 1887$)$, as amended, 49 U.S.C. $\$ 5(2)(f)(1952)$.

" $C$ Cf. United States v. Lowden, 308 U.S. 225 (I939); ICC v. Railway Labor Executives Ass'n, 315 U.S. 373 (I942); Railway Labor Executives Ass'n v. United States, 339 U.S. I42 (I950); The New Orleans Union Passenger Terminal Case, 282 I.C.C. 27 I (I952). 
employees must move, transporting their families and household goods, and selling their homes at whatever price they will bring in a collapsing real estate market. Railway workers have been able to get some degree of protection under such circumstances by the methods mentioned above. Their concern now is greatly heightened by the fact that the "Washington Agreement" needs extension to cover today's problems, and the recent amendment to the Interstate Commerce Act relative to abandonments or curtailments of service is a drastic change in government policy.

The two approaches, through direct collective bargaining or through legislative and ICC protection of displaced workers, tie in with the third course open to railway workers. The Railroad Unemployment Insurance Act now provides compensation up to $\$ 8.5^{\circ}$ per day for not more than twenty-six weeks in a benefit year. ${ }^{43}$ The cost of unemployment compensation is borne entirely by the carriers, and the payroll tax to meet the cost may rise or fall with the volume of unemployment. The Act is administered by the Railroad Retirement Board, one of the three members of which, by law, must be chosen from among persons named by the unions, and one from among management nominees.

Congress has recently enacted a statute that extends the period during which unemployment compensation will be paid to senior employees, and increases the compensation from the present fifty per cent to sixty per cent of the employee's earnings, with a maximum of $\$ 10.20$ per day. ${ }^{44}$ Railway employees urged this legislation both as a measure of justice to displaced older workers, many of whom are highly skilled in railway service but without skill for any outside employment, and as an incentive to the carriers to rehire experienced senior employees rather than to recruit new workers from outside the industry.

This legislation and all other efforts by railway employees to deal with the grave unemployment crisis have run head-on into a national publicity campaign of unprecedented intensity by railway managements. In the closing months of 1957 and the first eight months of 1958 , the carriers experienced a recession in traffic and revenues somewhat more than proportionate to the national decline. Recovery has been marked since September 1958. That is a standard, recurrent situation; any general drop in business brings about a drop in railway traffic of a little greater size, because inventory adjustment invariably means that the movement of goods drops more than either production or sales. On the other hand, as industries build inventories, with mounting business activity, more goods are transported than are currently being produced or sold. During each of the brief postwar recessions, railway management statements have seemed to indicate a belief that complete, final disaster was upon them. Demands for governmental assistance and vigorous attacks upon employees have marked each of those wis 69 Stat. 7I6 (I955), 45 U.S.C. $\$ 352$ (Supp. V, I958).

1173 Stat. 30, 45 U.S.C.A. \$\$ 351, 352 (1959). 
temporary dips in rail revenues. But the current campaign has been carried to lengths far greater than the 1949 or 1953 publicity drives. ${ }^{45}$

One aspect of this current publicity that threatens serious conflict is the demand for specific changes in the working rules of operating employees. ${ }^{40}$ Those rules were set up, for the most part, before World War I. They govern an incentive wage system. Many industries had such systems in the early years of this century, and at that time, the railway practices were no doubt as favorable to the employees as any in existence. Since then, railway technological change has combined with the improvement of incentive wage systems to make the railway rules appear inappropriate and out of adjustment. Significant movements for revisions were undertaken by operating employees in 1943, I953, and 1955. Union requests for modification of parts of the wage structure were, in general, approved in each of those movements. The carriers have asked for changes in recent years, but have abandoned their proposals during collective bargaining. Current carrier publicity makes much of the fact that the standard task of railway road-service men is expressed in terms of hours and days, and that it is an apparent anachronism to say that roo miles is an eight-hour day's work. Other apparent anachronisms in the wage structure of operating men have less publicity appeal. But a thorough study of the rules under which the incentive wage system functions will show many particulars in which railway operating men have been less favored than workers under other incentive wage systems.

Total employment on Class I carriers was over $2,000,000$ in $1920,{ }^{47} 1,500,000$ in I930, ${ }^{48}$ and $1,250,000$ in $1950 .^{49}$ The lowest annual average, until now, had been the 1938 figure of $939,000.50$ In December 1956, there were $1,016,000$ railway employees; in December 1957, 919,000; ${ }^{51}$ and in December 1958, 824,000. ${ }^{52}$ In 1957, the railways handled thirty per cent more traffic than in 1929, with forty per cent fewer employees; hence, the output per man-hour was $15^{\circ}$ per cent greater in 1957 than in $1929 .{ }^{53}$ Employment today is lower than it has been at any time in this century; man-hour productivity, at an all time peak.

Some comparative figures for other industries are available. From r939 to 1953, man-hour productivity in all United States manufacturing increased by

"Management 'Featherbed'?, Railway Age, Feb. 23, I959, p. I0; Wall Street Journal, Oct. I4, I959, p. 4; id., Oct. 19, 1959, p. I2; id., Oct. 27, 1959, p. 27. Similar advertisements have been carried in daily and weekly newspapers throughout the United States since the February 23 d inauguration of the campaign.

"Management 'Featherbed'?, Feb. 16, I959, pp. 9, 13.

${ }^{4}$ ICC, Statistics of Railways in the UNIted States xix (1920).

${ }^{48}$ Id., table 63, at S-53 (1930).

${ }^{10}$ ICC, Transport Statistics in the United States pt. I, table 63, at 48 (I957).

${ }^{50}$ See note 48 supra.

${ }^{6}$ ICC, Statement No. M-30o, Wage Statistics of Class I Railroads (1957).

63 Number of Employees at Middle of Month, ICC Preliminary Release, Dec. I958.

${ }^{23}$ ICC, Statement No. 25, Statistics of Railways in the United States, Productivity and Traffic xlix (I929); id., Statement No. 16, Statistics of Railways in the United States, EmployMent xxxvi (I929); id., Transport Statistics in the United States table 44, at 30 (I957); id., table 63 , at 48 . 
twenty-eight per cent; ${ }^{54}$ man-hour productivity of railway workers increased by fifty-nine per cent..$^{\overline{5}}$ From 1947 to 1957 , real product per man-hour in nonfarm industry rose 28.6 per cent; ${ }^{56}$ railway output rose 46.3 per cent per man-hour. ${ }^{57}$ These railway data include all traffic, passenger as well as freight.

The resentment felt by railway workers over the widely disseminated charges of "featherbedding," when their man-hour productivity has far outrun employee productivity in American industry generally, is heightened by the seemingly indifferent attitude of the carriers toward the heavy volume of railway unemployment. Railway employees also feel that the carriers' tactics have seriously crippled grievance procedures under the Railway Labor Act and have compounded the offense by forcing into its creaking compulsory arbitration 'machinery disputes of a kind that should be handled under other sections of the Railway Labor Act.

The railway labor situation is critical, more so now than it has been for perhaps a quarter century. Current wage agreements became subject to change as of November I, I959. ${ }^{58}$ Legislation affecting railway unemployment compensation is also at a critical stage. Carrier publicity has angered railway employees, arousing a great deal of bitterness, and the success of carrier demands for freedom in reducing service without regard for displaced employees will heap more fuel on that fire. The announced carrier intention to ask amendment of the working rules in ways that will adversely affect employment is explosive, particularly the proposal to run American freight trains and switch engines with only one man in the locomotive cab. It is not too much to say that war has been declared by the railway managements; it seems unlikely that anything which can be done by way of new legislation or by improved administration of that now on the statute books can avert a major crisis if the railways persist in their announced program.

\section{Conclusion}

Apart from any specific legislation aimed at any part of the railway or other transportation labor problems, it should be kept in mind that any changes in regulation of transportation will have a more or less direct effect upon employment and labor relations. The paradox of close governmental regulation of the industry and simultaneous government dedication to "free private competitive enterprise" makes it difficult to predict what form the transportation policy of the future will take. Railway managements again are urging their program of whole-

* U.S. Bureau of Labor Statistics, Dep't of Labor, Rep. No. 100, Trends in Output Per ManHour and Man-Hours Per Unit of Output, Manufacturing, 1939-53, table 4, at 315 (x955).

${ }^{50} I d$., Rep. No. r05, Trends in OUtPUT PeR MAN-HouR, 1935-55, table 6, at 8 (1956).

${ }^{\circ}$ U.S. Bureau of Labor Statistics, Dep't of Labor, Comparison of Indexes of Labor and Noniabor Payments, Prices, Real Earnings, and Productivity for the Private Nonfara Sector of the EcoNoMY, 1947-57, at 2 (1958).

"Statistical Abstract table 28r, at 226 (1958).

${ }^{82}$ Formal requests for wage increases have been served by organizations representing all railway $\mathrm{cm}$ ployees, and railway managements have countered with proposals for wage decreases. Management has also proposed drastic changes in virtually all basic working rules of the operating employees. Railway Age, Nov. 2, I959, p. 9. 
sale consolidations. The late Mr. Joseph B. Eastman, Federal Coordinator of Transportation under the Emergency Railroad Transportation Act of r933, and for many years a leading member of the ICC, seemed to favor integration of various types of transportation around a unified and public-owned railway system. Whether or not this may be the basis of transportation policy at some time in the future, it has no substantial support now among labor, management, government officials, or the general public.

Whatever may be the form of national transportation policy, it should recognize the fact that the need for adequate, efficient, and economical service can be met only if employee morale can be maintained. That, in turn, requires that transportation wages and working conditions progress in step with those in American industry generally and that the industry's technological readjustments be handled so as to impose a minimum of avoidable hardship upon the employees. Railway workers, by their responsible and intelligent attitude toward their own and the industry's problems, have earned and have been given the right to participate in determining transportation policy. That right should not now be curtailed; on the contrary, it should be extended to other groups of transportation workers as their organizations demonstrate the requisite responsibility. 